Brit. J. vener. Dis. (1956), 32, 104.

\title{
TPI TEST IN TREATED SYPHILIS *
}

\author{
BY \\ SIDNEY OLANSKY $\dagger$, AD HARRIS $\ddagger$, AND ELEANOR V. PRICE $\S$
}

\begin{abstract}
From the Venereal Disease Program, Division of Special Health Services, Public Health Service, Department of Health, Education, and Welfare, Washington, D.C.
\end{abstract}

The Treponema pallidum immobilization (TPI) test has received wide attention as a diagnostic test for syphilis, but few studies have appeared on the response of this test to adequate treatment for syphilis. The Blue Star study of the Public Health Service (Bauer, 1951; Shafer, Usilton, and Price, 1954) offered a group of patients who had had bona fide syphilis, who had been adequately treated, and who had been closely observed for many years after treatment.

The purpose of the present study is to determine the TPI results in these patients and to compare them with results of the VDRL slide and Kahn quantitative tests. When the Blue Star study patients were seen for their latest evaluation ( 5 to 9 years after treatment) blood was drawn and sent to the Venereal Disease Research Laboratory for the performance of the TPI, VDRL slide, and Kahn quantitative tests.

During the early years of the Blue Star study, which was initiated in 1945 , patients with any syphilitic diagnosis were accepted for study. As the study progressed and it was found that patients with secondary syphilis were the most satisfactory group for evaluating schedules of treatment, selections were limited to this stage. Therefore, of the 366 Blue Star patients who had TPI tests as of August, 1955, 213 were in the secondary stage at time of original treatment, 91 in the primary, 36 in the early latent stage, and only 22 in the late stages (twelve were diagnosed as having late latent syphilis, and ten as having symptomatic or asymptomatic neurosyphilis). In four patients treated before admission to the Blue Star study, the diagnosis at time of first treatment is unknown.

As shown in Table I (opposite), 305 of the patients received only one course of treatment. The remaining 61 patients were treated two or more times, some for relapse or resistance, others for re-infection. No

\footnotetext{
* Received for publication February 26, 1956.

$\dagger$ Formerly Director, Venereal Disease Research Laboratory, Chamblee, Georgia. Now at Department of Dermatology, Duke University School of Medicine, Durham, North Carolina.

$\ddagger$ Director, Venereal Disease Research Laboratory.

$\$$ Statistician, Venereal Disease Program, Division of Special Health Services, Public Health Service, Washington, D.C.
}

attempt has been made to distinguish between the two. In general, those receiving only one course of treatment represent patients successfully treated, though this group also includes a few patients who probably should have been re-treated but were not. The percentage reactive to the TPI test among those treated only once ranged from $3 \cdot 1$ in patients treated for sero-negative primary syphilis to 100 in patients who were in the late stages at time of treatment. Weakly reactive TPI tests were reported in 21 patients, twenty of whom had been treated for secondary syphilis.

Patients who were treated two or more times are tabulated in Table II (p. 106) by the original diagnosis and by the re-treatment diagnosis. Despite the small number of patients the influence of the original diagnosis is clearly evident. For example, in five patients originally treated for secondary syphilis and re-treated for sero-positive primary syphilis, one would assume re-infection. Only one of these was TPI non-reactive. Among patients treated for the first time for sero-positive primary syphilis, the non-reactive rate was $\mathbf{8 7 . 2}$ per cent. (see Table I). Similarly, in patients treated and re-treated for secondary syphilis, the non-reactive rate was 21.4 per cent. compared with 55.1 per cent. in patients treated for secondary syphilis for the first time.

No analysis is possible from the data available on the time required for the TPI to become nonreactive. These tests represent the first TPI evaluation of Blue Star patients and the majority have passed the period when the greatest change would be expected. More than 7 years had elapsed between treatment and the TPI test in 43 per cent. of the patients treated for primary or secondary syphilis and in 100 per cent. of the patients treated for latent or late syphilis.

Since the majority of relapses in early infectious syphilis occurred during the first year after treatment when Blue Star patients were on monthly examinations, it was possible to determine the time between the first indication of failure and retreatment of the patient. Among patients originally treated for primary or secondary syphilis who were re-treated within 1 month of the first indication of 
TABLE I

DIAGNOSIS AT TIME OF LAST TREATMENT AND RESULT OF TPI AT TIME OF LAST EXAMINATION

\begin{tabular}{|c|c|c|c|c|c|c|c|c|c|c|}
\hline \multirow{3}{*}{$\begin{array}{l}\text { Courses of } \\
\text { Treatment }\end{array}$} & \multirow{3}{*}{\multicolumn{3}{|c|}{$\begin{array}{l}\text { Diagnosis at Time of } \\
\text { Last Treatment }\end{array}$}} & \multirow{3}{*}{$\begin{array}{c}\text { Total } \\
\text { Examined }\end{array}$} & \multicolumn{6}{|c|}{ Result of TPI } \\
\hline & & & & & \multicolumn{2}{|c|}{ Reactive } & \multicolumn{2}{|c|}{ Weakly Reactive } & \multicolumn{2}{|c|}{ Non-reactive } \\
\hline & & & & & Number & Per cent. & Number & Per cent. & Number & Per cent. \\
\hline \multirow[t]{2}{*}{ One } & $\begin{array}{l}\text { Sero-negative } \mathbf{P} \\
\text { Sero-positive P } \\
\text { Secondary } \\
\text { Early Latent } \\
\text { Late Latent } \\
\text { Neurosyphilis }\end{array}$ & $\begin{array}{l}\text { Primary } \\
\text { Primary } \\
\ldots \\
\ldots \\
\ldots \\
\ldots\end{array}$ & $\begin{array}{l} \\
\cdots \\
\cdots \\
\cdots\end{array}$ & $\begin{array}{r}32 \\
47 \\
176 \\
32 \\
9 \\
9\end{array}$ & $\begin{array}{r}1 \\
5 \\
59 \\
30 \\
9 \\
9\end{array}$ & $\begin{array}{r}3 \cdot 1 \\
10 \cdot 6 \\
33 \cdot 5 \\
93 \cdot 8 \\
100 \cdot 0 \\
100 \cdot 0\end{array}$ & $\begin{array}{l}-1 \\
20 \\
- \\
-\end{array}$ & $\begin{array}{r}\theta .0 \\
2.1 \\
11.4 \\
0.0 \\
0.0 \\
0.0\end{array}$ & $\begin{array}{r}31 \\
41 \\
97 \\
2 \\
-\end{array}$ & $\begin{array}{r}96 \cdot 9 \\
87 \cdot 2 \\
55 \cdot 1 \\
6 \cdot 3 \\
0 \cdot 0 \\
0 \cdot 0\end{array}$ \\
\hline & Total & $\ldots$ & . & 305 & 113 & $37 \cdot \theta$ & 21 & 6.9 & 171 & $56 \cdot 1$ \\
\hline \multirow[t]{2}{*}{ Two } & $\begin{array}{l}\text { Sero-negative P } \\
\text { Sero-positive } \mathbf{P} \\
\text { Secondary } \\
\text { Early Latent } \\
\text { Late Latent } \\
\text { Neurosyphilis }\end{array}$ & $\begin{array}{l}\text { Primary } \\
\text { Primary } \\
\ldots \\
\ldots \\
\ldots \\
\ldots\end{array}$ & $\begin{array}{l} \\
\cdots \\
\cdots \\
\cdots\end{array}$ & $\begin{array}{r}2 \\
9 \\
18 \\
17 \\
3 \\
4\end{array}$ & $\begin{array}{r}-5 \\
11 \\
14 \\
3 \\
4\end{array}$ & $\begin{array}{r}0 \cdot 0 \\
55 \cdot 6 \\
61 \cdot 1 \\
82 \cdot 4 \\
100 \cdot 0 \\
100 \cdot 0\end{array}$ & $\begin{array}{l}-1 \\
1 \\
2 \\
-\end{array}$ & $\begin{array}{r}0.0 \\
11.1 \\
5.6 \\
11.8 \\
0.0 \\
0.0\end{array}$ & $\begin{array}{r}2 \\
3 \\
6 \\
1 \\
- \\
\end{array}$ & $\begin{array}{r}100 \cdot 0 \\
33 \cdot 3 \\
33 \cdot 3 \\
5.9 \\
0.0 \\
0.0\end{array}$ \\
\hline & Total & $\cdots$ & $\cdots$ & 53 & 37 & $69 \cdot 8$ & 4 & $7 \cdot 5$ & 12 & $22 \cdot 6$ \\
\hline \multirow[t]{2}{*}{$\begin{array}{l}\text { Three or } \\
\text { More }\end{array}$} & $\begin{array}{l}\text { Sero-negative P } \\
\text { Sero-positive P } \\
\text { Secondary } \\
\text { Early Latent } \\
\text { Late Latent } \\
\text { Neurosyphilis }\end{array}$ & $\begin{array}{l}\text { Primary } \\
\text { Primary } \\
\ldots \\
\ldots \\
\ldots \\
\ldots\end{array}$ & $\begin{array}{l} \\
\ldots \\
\ldots \\
\cdots\end{array}$ & $\begin{array}{l}- \\
2 \\
3 \\
2 \\
1\end{array}$ & $\begin{array}{l}- \\
1 \\
3 \\
2 \\
1\end{array}$ & $\begin{array}{r}- \\
50 \cdot 0 \\
100 \cdot 0 \\
100 \cdot 0 \\
100 \cdot 0\end{array}$ & $\begin{array}{l}E \\
z \\
z\end{array}$ & $\begin{array}{l}\overline{-} \\
\overline{0.0} \\
0.0 \\
0.0 \\
0.0\end{array}$ & $\begin{array}{l}- \\
- \\
-\end{array}$ & $\begin{array}{r}- \\
5 \overline{0} \\
0.0 \\
0.0 \\
0.0\end{array}$ \\
\hline & Total & $\ldots$ & $\ldots$ & 8 & 7 & $87 \cdot 5$ & - & 0.0 & 1 & $12 \cdot 5$ \\
\hline \multirow[t]{2}{*}{ Total } & $\begin{array}{l}\text { Sero-negative P } \\
\text { Sero-positive P } \\
\text { Secondary } \\
\text { Early Latent } \\
\text { Late Latent } \\
\text { Neurosyphilis }\end{array}$ & $\begin{array}{l}\text { Primary } \\
\text { Primary } \\
\ldots \\
\ldots \\
\ldots \\
\ldots \\
\end{array}$ & $\begin{array}{l} \\
\ldots \\
\ldots \\
\cdots\end{array}$ & $\begin{array}{r}34 \\
56 \\
196 \\
52 \\
14 \\
14\end{array}$ & $\begin{array}{r}1 \\
10 \\
71 \\
47 \\
14 \\
14\end{array}$ & $\begin{array}{r}2.9 \\
17.9 \\
36 \cdot 2 \\
90 \cdot 4 \\
100 \cdot 0 \\
100 \cdot 0\end{array}$ & $\begin{array}{r}- \\
21 \\
2 \\
- \\
\end{array}$ & $\begin{array}{r}0.0 \\
3.6 \\
10.7 \\
3.8 \\
0.0 \\
0.0 \\
\end{array}$ & $\begin{array}{r}33 \\
44 \\
104 \\
3 \\
- \\
\end{array}$ & $\begin{array}{r}97 \cdot 1 \\
78 \cdot 6 \\
53 \cdot 1 \\
5 \cdot 7 \\
0 \cdot 0 \\
0 \cdot 0\end{array}$ \\
\hline & Total & $\ldots$ & $\ldots$ & 366 & 157 & $42 \cdot 9$ & 25 & 6.8 & 184 & $50 \cdot 3$ \\
\hline
\end{tabular}

failure, 44.4 per cent. were non-reactive to the TPI test. The rate dropped to 25 per cent. in patients re-treated within 1 to 3 months and to zero when more than 3 months had elapsed before re-treatment.

A comparison of results of the TPI and VDRL slide tests (Table III, overleaf) revealed that approximately half of the patients with a reactive TPI were non-reactive to the VDRL. The rate varied by diagnosis at time of treatment ; from 66 per cent. in primary and secondary syphilis to 22 per cent. in late latent syphilis and to zero in neurosyphilis. Among patients with a weakly reactive TPI test, 90.5 per cent. were non-reactive to the VDRL slide test; and in the group non-reactive to the TPI test, 95.8 per cent. were non-reactive to the VDRL test. Two patients with reactive and five patients with weakly reactive VDRL tests were nonreactive to the TPI test. These patients were all treated only once, two during the primary stage and five in the secondary stage. The two patients reactive to the VDRL test were also reactive to the Kahn test, but one had been non-reactive to the Kolmer test for more than 3 years.

There are at least three possible explanations for the difference in the VDRL slide and TPI test results in these cases : (i) The TPI antibody may not have developed, since treatment could have been instituted before it was established.

(ii) These individuals may be more prone to reagin production than TPI antibody production.

(iii) A non-specific reaction in a patient treated for syphilis.

Which of these possibilities explains these cases cannot be determined. The expectancy is that TPI antibody will persist after reagin disappears, but the fact is that, after treatment for syphilis, reagin may persist in a small percentage of cases when the TPI antibody is not present.

Hundreds of patients who were unequivocally diagnosed as having early syphilis and were treated are now non-reactive to the TPI test. Some of these are still reactive to the reagin tests. The retrospective diagnosis in these cases would have to be "treated syphilis". A non-reactive TPI test does not necessarily mean then that the patient did not have syphilis at the time of treatment. The TPI test in patients previously treated for syphilis. is not as definitive therefore as it is in persons who have never received antisyphilitic therapy.

One factor known to influence the result of the TPI test is the duration of infection at time of 
TABLE II

RESULT OF TPI BY ORIGINAL AND RE-TREATMENT DIAGNOSIS

\begin{tabular}{|c|c|c|c|c|c|c|c|c|c|c|c|c|c|}
\hline \multirow{3}{*}{$\begin{array}{l}\text { Original } \\
\text { Diagnosis }\end{array}$} & \multirow{3}{*}{ TPI Results } & \multicolumn{12}{|c|}{ Re-treatment Diagnosis } \\
\hline & & \multicolumn{2}{|c|}{$\begin{array}{c}\text { Sero-negative } \\
\text { Primary }\end{array}$} & \multicolumn{2}{|c|}{$\begin{array}{c}\text { Sero-positive } \\
\text { Primary }\end{array}$} & \multicolumn{2}{|c|}{ Secondary } & \multicolumn{2}{|c|}{ Early Latent } & \multicolumn{2}{|c|}{$\begin{array}{c}\text { Late or Late } \\
\text { Latent }\end{array}$} & \multicolumn{2}{|c|}{ Total } \\
\hline & & $\begin{array}{c}\text { Num- } \\
\text { ber }\end{array}$ & $\begin{array}{c}\text { Per } \\
\text { cent. }\end{array}$ & $\begin{array}{c}\text { Num- } \\
\text { ber }\end{array}$ & $\begin{array}{l}\text { Per } \\
\text { cent. }\end{array}$ & $\begin{array}{l}\text { Num- } \\
\text { ber }\end{array}$ & $\begin{array}{l}\text { Per } \\
\text { cent. }\end{array}$ & $\underset{\text { ber }}{\text { Num- }}$ & $\begin{array}{l}\text { Per } \\
\text { cent. }\end{array}$ & $\begin{array}{l}\text { Num- } \\
\text { ber }\end{array}$ & $\begin{array}{c}\text { Per } \\
\text { cent. }\end{array}$ & $\begin{array}{l}\text { Num- } \\
\text { ber }\end{array}$ & $\begin{array}{l}\text { Per } \\
\text { cent. }\end{array}$ \\
\hline \multirow[t]{2}{*}{$\begin{array}{l}\text { Sero-negative } \\
\text { Primary }\end{array}$} & $\begin{array}{l}\text { Reactive } \\
\text { Weakly Reactive } \\
\text { Non-reactive }\end{array}$ & $\overline{1}$ & $\overline{100 \cdot 0}$ & $\overline{1}$ & $\overline{\overline{100} \cdot 0}$ & $\overline{1}$ & $\overline{\bar{E}}$ & $\bar{z}$ & $\bar{z}$ & $\bar{z}$ & 二 & $\overline{3}$ & $\overline{-}$ \\
\hline & Total & 1 & $100 \cdot 0$ & 1 & $100 \cdot 0$ & 1 & $100 \cdot 0$ & 一 & - & - & 一 & 3 & $100 \cdot 0$ \\
\hline \multirow[t]{2}{*}{$\begin{array}{l}\text { Sero-positive } \\
\text { Primary }\end{array}$} & $\begin{array}{l}\text { Reactive } \\
\text { Weakly Reactive } \\
\text { Non-reactive }\end{array}$ & E & E & $\frac{1}{1}$ & $\frac{50 \cdot 0}{50 \cdot 0}$ & $\frac{1}{2}$ & $\overline{63 \cdot 7}$ & $\begin{array}{r}2 \\
1 \\
-\end{array}$ & $\begin{array}{l}66 \cdot 7 \\
33 \cdot 3 \\
-\end{array}$ & $\frac{1}{-}$ & $\begin{array}{c}100 \cdot 0 \\
-\end{array}$ & $\begin{array}{l}5 \\
1 \\
3\end{array}$ & $\begin{array}{l}55 \cdot 6 \\
11 \cdot 1 \\
33 \cdot 3\end{array}$ \\
\hline & Total & 一 & - & 2 & $100 \cdot 0$ & 3 & $100 \cdot 0$ & 3 & $100 \cdot 0$ & 1 & $100 \cdot 0$ & 9 & $100 \cdot 0$ \\
\hline \multirow[t]{2}{*}{ Secondary } & $\begin{array}{l}\text { Reactive } \\
\text { Weakly Reactive } \\
\text { Non-reactive }\end{array}$ & $\frac{-}{1}$ & $\overline{100 \cdot 0}$ & $\begin{array}{l}3 \\
1 \\
1\end{array}$ & $\begin{array}{l}60 \cdot 0 \\
20 \cdot 0 \\
20 \cdot 0\end{array}$ & $\begin{array}{r}10 \\
1 \\
3\end{array}$ & $\begin{array}{r}71 \cdot 4 \\
7 \cdot 1 \\
21 \cdot 4\end{array}$ & $\begin{array}{r}11 \\
1 \\
1\end{array}$ & $\begin{array}{r}84 \cdot 6 \\
7 \cdot 7 \\
7 \cdot 7\end{array}$ & - & $\begin{array}{c}100 \cdot 0 \\
-\end{array}$ & $\begin{array}{r}28 \\
3 \\
6\end{array}$ & $\begin{array}{r}75 \cdot 7 \\
8 \cdot 1 \\
16 \cdot 2\end{array}$ \\
\hline & Total & 1 & $100 \cdot 0$ & 5 & $100 \cdot 0$ & 14 & $100 \cdot 0$ & 13 & $100 \cdot 0$ & 4 & $100 \cdot 0$ & 37 & $100 \cdot 0$ \\
\hline \multirow[t]{2}{*}{ Early Latent .. } & $\begin{array}{l}\text { Reactive } \\
\text { Weakly Reactive } \\
\text { Non-reactive }\end{array}$ & E & Z & $\frac{1}{-}$ & $\frac{100 \cdot 0}{-}$ & $\frac{1}{1}$ & $\frac{50 \cdot 0}{50 \cdot 0}$ & - & $\frac{100 \cdot 0}{-}$ & E & E & $\frac{3}{1}$ & $\frac{75 \cdot 0}{25 \cdot 0}$ \\
\hline & Total & - & 一 & 1 & $100 \cdot 0$ & 2 & $100 \cdot 0$ & 1 & $100 \cdot 0$ & - & - & 4 & $100 \cdot 0$ \\
\hline \multirow[t]{2}{*}{$\begin{array}{c}\text { Late or Late } \\
\text { Latent }\end{array}$} & $\begin{array}{l}\text { Reactive } \\
\text { Weakly reactive } \\
\text { Non-reactive }\end{array}$ & E & E & E & $\bar{z}$ & E & $\bar{E}$ & - & $\begin{array}{c}100 \cdot 0 \\
-\end{array}$ & - & $\begin{array}{c}100 \cdot 0 \\
-\end{array}$ & - & $\frac{100 \cdot 0}{-}$ \\
\hline & Total & - & - & - & - & - & - & 1 & $100 \cdot 0$ & 3 & $100 \cdot 0$ & 4 & $100 \cdot 0$ \\
\hline \multirow[t]{2}{*}{ Total* } & $\begin{array}{l}\text { Reactive } \\
\text { Weakly Reactive } \\
\text { Non-reactive }\end{array}$ & $\overline{-}$ & $\overline{-}$ & $\begin{array}{l}5 \\
1 \\
3\end{array}$ & $\begin{array}{l}55 \cdot 6 \\
11 \cdot 1 \\
33 \cdot 3\end{array}$ & $\begin{array}{r}12 \\
1 \\
7\end{array}$ & $\begin{array}{r}60 \cdot 0 \\
5 \cdot 0 \\
35 \cdot 0\end{array}$ & $\begin{array}{r}17 \\
2 \\
1\end{array}$ & $\begin{array}{r}85 \cdot 0 \\
10 \cdot 0 \\
5 \cdot 0\end{array}$ & $\frac{10}{-}$ & $\frac{100 \cdot 0}{-}$ & $\begin{array}{r}44 \\
4 \\
13\end{array}$ & $\begin{array}{r}72 \cdot 1 \\
6 \cdot 6 \\
21 \cdot 3\end{array}$ \\
\hline & Total & 2 & $100 \cdot 0$ & 9 & $100 \cdot 0$ & 20 & $100 \cdot 0$ & 20 & $100 \cdot 0$ & 10 & $100 \cdot 0$ & 61 & $100 \cdot 0$ \\
\hline
\end{tabular}

* Total includes four cases with unknown diagnosis at time of first treatment.

TABLE III

COMPARISON OF RESULTS OF TPI AND VDRL TESTS ON SAME SPECIMEN

\begin{tabular}{|c|c|c|c|c|c|c|c|c|c|c|}
\hline \multirow{3}{*}{\multicolumn{2}{|c|}{ Result of TPI }} & & \multicolumn{8}{|c|}{ Result of VDRL Slide Test } \\
\hline & & & \multicolumn{2}{|c|}{ Reactive } & \multicolumn{2}{|c|}{ Weakly Reactive } & \multicolumn{2}{|c|}{ Non-reactive } & \multicolumn{2}{|c|}{ Total } \\
\hline & & & Number & Per cent. & Number & Per cent. & Number & Per cent. & Number & Per cent. \\
\hline $\begin{array}{l}\text { Reactive } \\
\text { Weakly reactive } \\
\text { Non-reactive }\end{array}$ & $\begin{array}{l}\cdots \\
\cdots\end{array}$ & $\begin{array}{l}\cdots \\
\cdots\end{array}$ & $\begin{array}{r}32 \\
1 \\
2\end{array}$ & $\begin{array}{r}28 \cdot 8 \\
4 \cdot 8 \\
1 \cdot 2\end{array}$ & $\begin{array}{r}23 \\
1 \\
5\end{array}$ & $\begin{array}{r}20.7 \\
4.8 \\
3.0\end{array}$ & $\begin{array}{r}56 \\
19 \\
160\end{array}$ & $\begin{array}{l}50.5 \\
90.5 \\
95.8\end{array}$ & $\begin{array}{r}111 \\
21 \\
167\end{array}$ & $\begin{array}{l}100 \\
100 \\
100\end{array}$ \\
\hline Total $\ldots$ & $\ldots$ & $\ldots$ & 35 & $11 \cdot 7$ & 29 & $9 \cdot 7$ & 235 & $78 \cdot 6$ & 299* & 100 \\
\hline
\end{tabular}

* Six cases with no VDRL test have been omitted.

treatment. This is evident by the reactivity rates for the various stages of syphilis. The actual duration of infection is unknown in most instances, for the duration indicated generally represents the period during which the patient was aware of lesions. Among patients treated for secondary syphilis with lesions of 1 to 7 days' duration, the TPI test was reactive in 4.8 per cent. and non-reactive in 81 per cent.

In patients with lesions of 60 days' duration or more the TPI test was reactive in $57 \cdot 1$ per cent. and non-reactive in 35.7 per cent. In the periods between these two extremes, 8 to 14 days, 15 to 29 days, and 30 to 59 days, little variation was noted. The reactivity rates ranged from 28.6 to 33.3 per cent. and the non-reactivity rate from 50 to 58.9 per cent.

Also of significance is the length of time required for the serologic test for syphilis (Kahn) to become non-reactive. This is well illustrated in Fig. 1 (opposite). The reactivity rate of the TPI test steadily increased from $3 \cdot 1$ per cent. among patients 


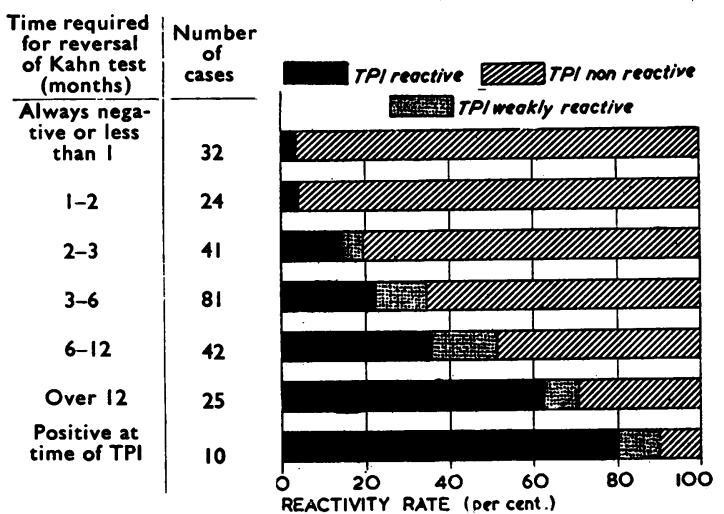

FIG. 1.-Result of TPI test in relation to time required for Kahn test to reverse to negative in primary or secondary syphilis.

always non-reactive or who reversed within 1 month following treatment to 80 per cent. among patients with a reactive Kahn at the time of the TPI test. Patients who required more than 3 months but less than a year to become non-reactive had the highest percentage of weak reactions to the TPI test.

Although Fig. 1 is based on a total of primary and secondary syphilis, the same relationship between the time taken to become non-reactive and the TPI result exists in both primary and secondary syphilis.

The height of the pre-treatment serologic titre (Kahn units) in relation to the result of the TPI test is shown in Fig. 2. In general, the higher the titre, the longer the time required to reverse the STS ; and, as shown in Fig. 1, the longer the time required for reversal, the greater the percentage of reactive TPI tests. To eliminate the effect of delayed reversal, Fig. 2 has been limited to patients becoming non-reactive within 6 months after treatment. The black and shaded sections of the columns represent reactive and weakly reactive TPI tests

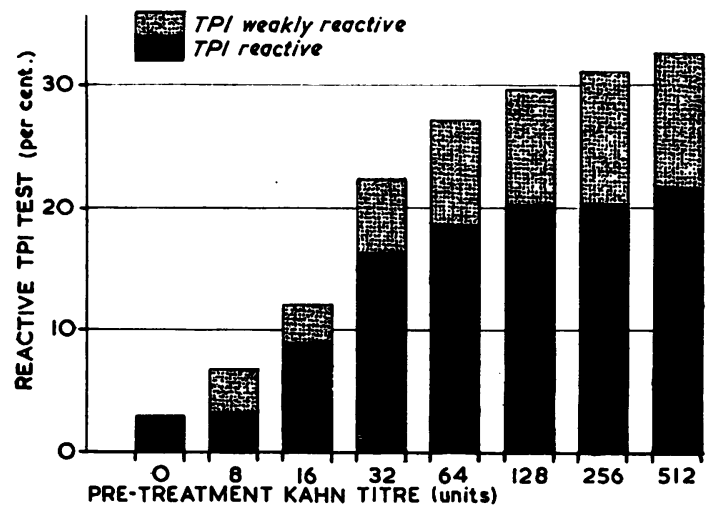

Fig. 2.-Result of TPI in relation to pre-treatment Kahn titre in primary or secondary syphilis. respectively. Although there is a gradual increase in reactive or weakly reactive TPI tests with the increase in titre, the greatest difference is observed between 16 and 32 units. After this point the increase is slight and is reflected principally in the weak reactions.

The three factors discussed above, namely, duration of infection, length of time required for the STS to become non-reactive, and the height of the pre-treatment titre, are so interrelated that it is difficult to determine the relative influence of each on the result of the TPI test. This has been attempted, however, by holding two of the factors constant while measuring the effect of the third. Table IV, based on patients with secondary syphilis, measures the effect of time required for the reversal of the STS, duration of infection and pre-treatment titre being held constant.

TABLE IV

TIME REQUIRED FOR REVERSAL OF STS IN SECONDARY SYPHILIS, DURATION OF INFECTION, AND PRE-TREAT. MENT TITRE BEING HELD CONSTANT

\begin{tabular}{|c|c|c|c|c|c|}
\hline \multirow{2}{*}{$\begin{array}{c}\text { Duration of } \\
\text { Infection } \\
\text { (days) }\end{array}$} & \multirow{2}{*}{$\begin{array}{c}\text { Pre- } \\
\text { treatment } \\
\text { Kahn Titre }\end{array}$} & \multirow{2}{*}{\multicolumn{2}{|c|}{$\begin{array}{c}\text { Time required for } \\
\text { Reversal of STS } \\
\text { (months) }\end{array}$}} & \multicolumn{2}{|c|}{ Per cent. TPI } \\
\hline & & & & Reactive & $\begin{array}{l}\text { Non- } \\
\text { reactive }\end{array}$ \\
\hline \multirow{4}{*}{60 or more } & \multirow[t]{2}{*}{$\begin{array}{ll}128 & \text { units } \\
\text { or more }\end{array}$} & $\begin{array}{l}6 \text { or more } \\
\text { Less than } 6\end{array}$ & 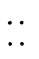 & $\begin{array}{l}52.9 \\
45 \cdot 5\end{array}$ & $\begin{array}{l}41 \cdot 2 \\
36 \cdot 4\end{array}$ \\
\hline & & Difference & $\ldots$ & $7 \cdot 4$ & $4 \cdot 8$ \\
\hline & \multirow[t]{2}{*}{$\begin{array}{l}\text { Less than } \\
128 \text { units }\end{array}$} & $\begin{array}{l}6 \text { or more } \\
\text { Less than } 6\end{array}$ & $\cdots$ & $\begin{array}{l}80 \cdot 0 \\
66.7\end{array}$ & $\begin{array}{l}20 \cdot 0 \\
33 \cdot 3\end{array}$ \\
\hline & & Difference & $\ldots$ & $13 \cdot 3$ & $-13 \cdot 3$ \\
\hline \multirow{5}{*}{ Less than 60} & \multirow[t]{2}{*}{$\begin{array}{cc}128 & \text { units } \\
\text { or more }\end{array}$} & $\begin{array}{l}6 \text { or more } \\
\text { Less than } 6\end{array}$ & $\cdots$ & $\begin{array}{l}48 \cdot 7 \\
17 \cdot 0\end{array}$ & $\begin{array}{l}35.9 \\
69.8\end{array}$ \\
\hline & & Difference & $\cdots$ & $31 \cdot 7$ & -33.9 \\
\hline & \multirow[t]{2}{*}{$\begin{array}{r}\text { Less than } \\
128 \text { units }\end{array}$} & $\begin{array}{l}6 \text { or more } \\
\text { Less than } 6\end{array}$ & $\begin{array}{l}\cdots \\
\cdots\end{array}$ & $\begin{array}{l}41 \cdot 7 \\
12 \cdot 1\end{array}$ & $\begin{array}{l}41 \cdot 7 \\
81 \cdot 8\end{array}$ \\
\hline & & Difference & .. & 29.6 & $-40 \cdot 1$ \\
\hline & & \multicolumn{2}{|c|}{ Average Difference } & $20 \cdot 5$ & $-20 \cdot 6$ \\
\hline
\end{tabular}

Similar comparisons were made for duration of infection, pre-treatment titre and time required for reversal of STS being held constant; and for pre-treatment titre, duration of infection and time required for reversal of STS being held constant.

The average differences in percentages are shown in Table $\mathrm{V}$.

TABLE V

AVERAGE DIFFERENCES IN PERCENTAGES

\begin{tabular}{ll|ll|c}
\hline \multirow{2}{*}{ Factor } & & \multicolumn{2}{c}{ TPI } \\
\cline { 2 - 4 } & & Reactive & Non-reactive \\
\hline Duration of Infection & $\ldots$ & $\ldots$ & 31.4 & -24.6 \\
\hline Time required for Reversal of STS & 20.5 & -20.6 \\
\hline Pre-treatment Titre & $\ldots$ & $\ldots$ & -9.1 & 1.6 \\
\hline
\end{tabular}


Patients with a duration of infection of 60 days or more had an average of 31.4 per cent. more reactive TPI tests and 24.6 per cent. less nonreactive TPI tests than patients with a duration of infection of less than 60 days at time of treatment. Patients requiring more than 6 months for reversal of the STS had an average of 20.5 per cent. more reactive TPI tests and 20.6 per cent. less nonreactive tests than patients in whom the STS became non-reactive within 6 months after treatment. It will be observed, however, that patients with high titres had fewer reactive tests and more non-reactive tests than patients with low pretreatment titres.

These data suggest that the duration of infection is the most important factor affecting the TPI result, that time required for reversal of the STS comes next, and that the pre-treatment titre is either of no significance or has an inverse relationship. The latter is probably the case, as patients with low titres requiring more than 6 months for the STS to become non-reactive had a higher percentage of reactive TPI tests and a lower percentage of non-reactive TPI tests than patients with high titres who required more than 6 months for the STS to become non-reactive.

\section{Summary}

(1) A considerable number of patients will be non-reactive to the TPI test some time after adequate treatment for primary or secondary syphilis.

(2) The duration of syphilis before treatment is the most important factor in determining the TPI reactivity rate after therapy.

(3) Some few patients who have non-reactive TPI tests after adequate treatment for syphilis are reactive in the VDRL slide test.

(4) A non-reactive result by the TPI test is less definitive in patients previously treated for syphilis than in untreated patients.

\section{REFERENCES}

Bauer, T. J. (1951). J. vener. Dis. Inform., 32, 355.

Shafer, J. K., Usilton, L. J., and Price, E. V. (1954). Bull. Wld Hlth Org., 10, 563. 